\title{
The Meaning of the Ark of the Covenant through the Logos Heuristics
}

\author{
Antonio Cassella ${ }^{1}$ \\ ${ }^{1}$ President of Research Autism LLC (FL) and Director of Imerisya (Instituto merideño de investigación de la inteligencia \\ social y del autismo, Mérida, Venezuela). \\ Correspondence: Antonio Cassella, 1270 N. Wickham Rd. 16-613, Melbourne, FL, 32935, USA.
}

Received: January 11, 2019

doi:10.11114/ijsss.v7i2.4080

\begin{abstract}
By placing the Ark of the Covenant in the first Jewish Temple in the $10^{\text {th }}$ century before the Common Era (BCE), King Solomon relieved Levite priests from carrying the Ark. Three centuries later, King Josiah of Judah asked the Levites to return that container to the Temple, implying that it was no longer there. The gold-plated Ark enclosed more than an unvarying law in the Decalogue and the 'obedience' of classical-computing attached to the crystal Thummim sewed by Moses into the Ephod worn by Aaron, the first high priest. Moses also placed in his brother's vest the crystal Urim, or flexible variations 'between obedience and disobedience', in the quantum-computing epitomized by the 'tree-of-the-knowledge-of-good-and-evil' (Genesis 2). Together, the Thummim and Urim crystals embody the Wisdom ascribed to nature's Nature and the 'Tree-of-Life'. Solomon shared this Wisdom with the visiting Queen of Sheba. Although the Ark may have never followed the return of that queen into Ethiopia, her mariners could have shared Solomon's Wisdom with Greek, Hindu, Chinese, and Olmec sages. This hypothesis addresses the simultaneous rise in the $6^{\text {th }}$ century BCE of the Logos posited by Heraclitus in Greek-Ionia; Dharma in Hinduism; the meaning 'thus-gone and-come' in the name "Tathāgatha" of the Buddha; Social Intelligence in the mythical meeting of Laozi with Kong-Fuzi in China; and, among the Mesoamerican Olmecs, of the legend about the bird-serpent that the Aztecs called later "Quetzal-coatl." The classical-quantum power of the 'thus-gone-and-come' Quetzalcoatl to save humans and nonhuman species from obliteration matches the will of readers eager to catch the esoteric meaning of the vanished Ark.
\end{abstract}

Keywords: Ark-of-the-Covenant, classical-computing-Thummim, quantum-computing-Urim, Dharma, Logos, nature's-Nature, Social intelligence, Quetzalcoatl, tree-of-the-knowledge-of-good-and-evil, Tree-of-Life, Wisdom

\section{Introduction}

We do not know if the Ark that is safeguarded in the Ethiopian city of Axum is the same Ark of the Covenant that was once held in Solomon's Temple and later vanished. In the $10^{\text {th }}$ century BCE, ${ }^{1}$ King Solomon shared with the visiting Queen of Sheba the esoteric meaning of two objects placed by Moses in the Ark: The crystals Thummim and Urim. Beyond the possibility that the Ark followed the return of the Queen of Sheba into Ethiopia, I posit here that her ships carried East and West of Africa the mystic implications of the union of the two crystals.

In Exodus (28:30, NLT $^{2}$ ) the Lord told Moses, "Insert the Urim and Thummim into the sacred chestpiece so they will be carried over Aaron's heart when he goes into the Lord's presence.” About 35 centuries after Moses, the American/Yaqui Man-of-knowledge Don Juan told the anthropologist Carlos Castaneda (1968) in Mexico, "Before you embark on any path ask the question: Does this path have a heart?" Answering Don Juan's question (Castaneda, 1974) implies balancing in one's heart two different aspects of Wisdom: The Tonal (Thummim, or autistic classical computing) and the Nagual (Urim, or artistic quantum computing, between autism ${ }^{3}$ and psychosis ${ }^{4}$ ).

Don Juan's words suggest that Solomon's will to share with faraway sages the roots of divinity did not fail. Still, the fact that the terrorism unleashed by malevolent leaders (1), global warming (2), the adoration of known order supported by autism (3), and the chaos attached to psychosis (4) (the four horsemen of Apocalypse) are on the increase proves that

\footnotetext{
1 Before the Common Era.

2 NLT: New Living Translation.

3 At this time, there are at least 80 million autistics in the world.

${ }^{4}$ I include schizophrenia (60 million), depression (270 million), and bipolar disorder (60 million) in the psychosis that distorts the perception of reality in $5 \%$ of the world population.
} 
unsmiling characters and their stern followers have not grasped yet the union of rigid obedience in the crystal Thummim with flexible criticism in the crystal Urim.

This article seeks to refund the smiles of our young and natural beauty by adding crucial implications into Moses' will to use the Ark of the Covenant as a repository of Wisdom. As an adopted Prince of Egypt, Moses knew from the 'House of Thoth' about the problem-solving Crossing of the rigid Crook and flexible Flail on Osiris' chest. As the Jew who re-organized the oral tradition of his blood relatives, he was also acquainted with the merger of rigidity and flexibility in the Crossing of Thummim with Urim. ${ }^{5}$

For example, consider Moses' account of Genesis in which Jacob ran away from his Thummim-home after stealing his brother's blessing from Isaac, their almost-blind father. In Bethel, Jacob dreamt of the ascent and descent of angels on a ramp $^{6}$ that went from the earth to the sky. The ascent represents quantum coherence in the Urim that generates different solutions to a problem; and the descent represents the quantum decoherence that unites Urim to Thummim in choosing a solution that renovates progress and beauty. Another example is the blessing that the angel Gabriel bestowed to Israel (Jacob) in Penuel. Gabriel recognized there that Israel's will to 'win with' others had replaced Jacob's will to 'win over' others.

God's blessing also favored Joseph, the son of Israel and Rachel. Joseph became the Vice-Pharaoh of Egypt, saved it from famine, and welcomed his relatives there in the $19^{\text {th }}$ century BCE. Pharaoh valued Joseph because Egyptians already appreciated the Wisdom attached to the Crossing of reality in a rigid Crook with ingenuity in a flexible Flail. Ancient Egyptians thanked Osiris for our true memory of the law (Thummim), for the uniplural ingenuity (Urim) that allows us to change the law, and for discerning (joining Thummim to Urim) when change should override memory. They knew that, taking aside the mad, all humans have the first gift; most people have the second one; and the third gift fills only those who 'walk-with-God'. Joseph was one of them.

Four centuries after the discernment of Joseph, Moses 'walked-with-God' by reinforcing the Crossing of classical reality and quantum vision when he sewed the crystals Thummim and Urim in the Ephod kept in the Ark of the Covenant. Moses' feat served the roots of Wisdom to Solomon, the Queen of Sheba, and the Sages who took them in. Zechariah, for example, warned us in the $6^{\text {th }}$ century BCE that God would break his staff No'am and after that, his staff Hovalim. If we matched No'am with Urim - and Hovalim with Thummim, we will conclude that the efforts of Moses, Solomon, and the Queen of Sheba to share the meaning of the Alliance of flexibility and rigidity have been enriched by a few discerning minds.

Indeed, twenty-nine centuries after the reign of Solomon and about a century before Don Juan, Joseph Smith used in America the Alliance of the crystals Thummim and Urim (or classical and quantum computing) to translate the Book of Mormon. Unfortunately, most of us are still unaware of the meaning of the crystals Thummim and Urim and of their reflection in Zechariah's staffs No'am and Hovalim. Nevertheless, we could fulfill the aims of Progress by going back 26 centuries to re-examine the 'uniplural' Logos described by Heraclitus. The Logos of that Ionian-Greek philosopher calls for allying rigidity with flexibility, similar to the Egyptian Crossing of the Crook with the Flail, Moses' Union of the crystals Thummim with Urim, or the reciprocal empowerment of Hovalim with No'am, the Tonal with the Nagual, and classical with quantum computing.

My early research (Cassella, 1997, 2000) on the quantum computing weakened in autism shows that Heraclitus' Logos contains the roots of Moses' and Solomon's Wisdom. I added later (Cassella, 2002) an expression of the cognitive principles behind the $1^{\text {st }}$ attention spared in autism and the principles of the $2^{\text {nd }}$ attention damaged in the autistic brain. Within the logos heuristics (Cassella, 2002, 2008, 2011, 2014, 2017a, 2017b, 2018a, 2018b, 2018c, 2018d, 2018e, 2018f), I posited that the $1^{\text {st }}$ attention in the autistic spacetime of the crystal Thummim follows the principles that

a) no object can exist in two or more places simultaneously (Locality); and that two or more objects cannot share the same space at the same time (Impenetrability).

I also posited that hyperspace (Caramazza, 1994) in the $2^{\text {nd }}$ attention of the crystal Urim goes by the principles that

b) the same object can exist in two or more places at the same time (Ubiquity); and that two or more objects can share the same space at the same time (Coincidence).

Although they may seem to contradict each other, classical spacetime (Cassella, 1997, 2000) in the $1^{\text {st }}$ attention and quantum hyperspace in the $2^{\text {nd }}$ attention (i.e. the Crook and the Flail, Thummim and Urim, Hovalim and No'am, or the Tonal and the Nagual) can reinforce each other within Progress (Cassella, 2002). In favoring Progress, I align:

\footnotetext{
5 Moses assembled the five books of the Pentateuch.

${ }^{6}$ Ancient Hebrew points at an earth-supported ramp, not a ladder (Alter, 1996).
} 
1. the primary way of Kong-Fuzi in the $6^{\text {th }}$ century BCE (Kong-Fuzi, 1995) to classical computing and the $1^{\text {st }}$ attention in spacetime;

2. the secondary way of Laozi (Lao Tze, 1891), to quantum computing and the $2^{\text {nd }}$ attention in hyperspace; and

3. the Middle Way of the Buddha (Villalba, 1989), to an integration of Kong-Fuzi's Analects and Laozi's Tao-Te-Ching in the $3^{\text {rd }}$ Attention.

I also found the $3^{\text {rd }}$ Attention in the discourse held by Lord Khrishna and Arjuna in the Bhagavad Gittā, in the verses of Vālmīki's Rāmāyana, the Maya Sacred Text Popol Vuh, and the Mesoamerican myth of the return of a flying-serpent, or "Quetzal-coatl" to the Aztecs. The myth of Quetzalcoatl can be taken as a token of the Progress that would follow our comprehension of the Alliance of the measurable Thummim and the uniplural Urim.

The marriage of visible reality with uniplural ingenuity enlivens the Logos expressed by Heraclitus, the Catholic Eucharist, the Night Journey of Muhammad to the Farthest Mosque and back to Mecca, and the views of Divine learning in all Sacred Texts in which the memory of repetitive rigidity marries silently the change advised by uniplural flexibility. Uniplural quantum computing also enlivens the Crossing of the Thummim and Urim crystals in Aaron's Ephod, the Crossing of the Crook and the Flail on the chest of Osiris, the metaphorical Crossing of the classical head of Giza's Sphinx with its quantum body (Cassella, 2018e), and even a Crossing left in Gorham's Cave 40000 years ago (Rodríguez-Vidal et al, 2014; Cassella, 2016).

The writings of Antonio Rosmini, an Italian priest-philosopher of the early $19^{\text {th }}$ century CE (Common Era), implied that the selfless use (the $3^{\text {rd }}$ Attention) of uniplurality (the $2^{\text {nd }}$ attention or 'being-and-nonbeing') renovates the reality (the $1^{\text {st }}$ attention or 'being') of any individual and society. Because memory of reality is spared, and uniplurality impaired, in the autistic brain - and because the Ark-of-the-Covenant-human-brain is a repository of the union of uniplurality-Urim and reality-Thummim, uncovering the roots of autism will bring an understanding of the meaning of the Ark and Progress.

Whether the Tabot guarded in Axum represents or not the vanished Ark, I propose that Axum could host a Council of all Churches to examine the Union of classical and quantum computing in the Divine, nature, the human mind, any society, and Progress. Following the controversial thought of Rosmini, ${ }^{7}$ a renovated agreement about the roots of nature, religion, Progress, and Divinity might stop the maliciousness of tyrants, reduce the ignorance of terrorists, and reverse the increase of autism and psychosis, while favoring the cooling of the lower atmosphere and the hope and smile of our young.

\section{Method}

In subsequent sections, the 'Background' presents the hypotheses behind the meaning of the Ark of the Covenant, the 'Discussion' substantiates and integrates them, and the 'Conclusion' summarizes relevant consequences.

\section{Background}

\subsection{The Jewish-Ethiopian Connection}

In 1940, I was born in Addis-Ababa, the cradle of humanity at 350 miles from Axum - the northern city of Ethiopia that hosts the 'Ark of the Covenant' in the "Chapel of the Tablet." In that Christian Temple, the Ethiopian Orthodox Tewahedo Church continues protecting the Guardian of the Ark, the only human allowed to see the 'Tabot' linked to a memory venerated in all Abrahamic religions.

Abrahamic Sacred Texts attribute the origins of the Ark to the will of an 80-year-old Moses, after he took his Jewish relatives out of Egypt in the $15^{\text {th }}$ century BCE. Moses placed in the Ark the secret of the Nature of Divinity, of the rise and fall of any natural system, the humane mind, and Wisdom. In my view, King Solomon unveiled that secret in the $10^{\text {th }}$ century BCE, before building in Jerusalem a reflection of the 'House-of-God' that Jacob had dreamed of in Bethel and the 'Holy of Holies' in which he welcomed the "Face-of-God" that Israel had met in Penuel.

By placing the Ark of the Covenant in the First Jewish Temple, King Solomon freed Levite priests from carrying it around. However, in the $6^{\text {th }}$ century BCE King Josiah of Judah said to the Levites (2 Chronicles 35:3, NLT): "Put the Holy Ark in the Temple that was built by Solomon son of David, the king of Israel. You no longer need to carry it back and forth on your shoulders ..." Josiah's words implied that the Ark had left Solomon's Holy of Holies. The testimony of King Josiah concurred with the tradition legitimized by the Ethiopian Kebra Nagast in the $14^{\text {th }}$ century CE. According to the Kebra Nagast, at the turn of the $10^{\text {th }}$ century BCE, the Ark followed Menelik I, the son of Solomon and the Queen of Sheba. 21 years earlier, she had gone to Israel in order to compare her Wisdom to Solomon's.

\footnotetext{
${ }^{7}$ His book "Delle cinque piaghe della santa Chiesa" was placed in the Index of Forbidden Books (IFB) in 1849. The IFB was abolished in 1966; and Rosmini's works were re-appreciated by the Catholic Church in 2001.
} 
I presume that King Solomon perceived the dangers that menaced his kingdom. Two centuries after his reign, the Assyrian Tiglath-Pileser III and his son Shalmaneser left Nineveh (Iraq) to conquer Israel. In the $6^{\text {th }}$ century BCE, the Babylonians conquered the Assyrians and destroyed the first Jewish Temple. Hence, one can even surmise that Solomon had the foresight to willingly send the Ark to safety from Israel to remote Ethiopia. There is no proof, however, that the original Ark ever reached the Ethiopian highlands; e.g. through the Blue Nile, and then through the Ethiopian "Lake Tana" up to Axum, as Graham Hancock (1992) suggested. Neither is it proven that the Ark left the eastern port of Aqaba to enter a western port of the Red Sea. ${ }^{8}$ Similarly, one may suppose that the Kebra Nagast supported the view that Solomonic Ethiopian emperors had been reigning for about 3000 years up to the time of Haile Selassie's death in 1975. I align with the possibility that the Ark and its contents did reach Axum, while its golden topping stayed behind.

Actually, Ethiopian highlands did host some members of the 10 Lost Tribes of Israel, until Operation Solomon airlifted 14325 Beta-Israel Jews into Israel in 1991. The presence of ancient Judaism for about 30 centuries in Ethiopia strengthens the hypothesis that King Solomon shared with the Queen of Sheba ( $1^{\text {st }}$ Kings 10:1-13) his esoteric understanding of the oral accounts collected by Moses in the Pentateuch and of the objects he left in the Ark.

The written re-organization of Jewish Sacred Texts occurred in the $6^{\text {th }}$ century BCE, after the Persian emperors Cyrus the Great, his son Cambyses II, and Darius the Great encouraged the exiled Jews to return from Babylon to Israel and to reconstruct Solomon's Temple. Due to the ambiguity of several words conveyed in the original Hebrew texts, I will rely on the translation and comments of Alter (1996) to review key aspects of the Power of Divinity.

\subsection{The Covenant of God with Abraham, the First Patriarch}

According to Robert Alter, the Adam-maleness remained when the Eve-femaleness was separated from the initial "adam" - an interpretation that highlights the value of women's vision in any society. Moreover, because the Creator took the human genome from dust, or "adamah," one may hypothesize that the 'togetherness of Adam and Eve' is a metaphor for the uniplural unity in diversity of the Divine and of nature's Nature. My assumption that the female-Urim preceded the male-Thummim is strengthened by the account that, after eating the fruit of the tree-of-the-knowledge-of-good-and-evil, Eve and Adam were eager to eat the fruit of the Tree-of-Life (Genesis 3:22, NLT), which promised them the possession of God's Power.

At that point, the Creator protected Adam and Eve by sending them away and by placing the flaming sword of two Cherubim near the Tree-of-Life. Still, God consigned the proof of his Covenant with life on Earth in any "rainbow." Indeed, any 'rainbow' (Cassella, 2002) stands for the de-coherence that unites quantum with classical computing, within the Progress that follows the death of the old and the birth of the new.

The rainbow must have glowed in the eyes of Noah when his Ark survived the flooding that had afflicted the Earth. Abraham, one of Noah's descendants, was selected by God to carry on the message of Salvific Progress. God's promise to the First Patriarch Abraham is exemplified in His words, "All the families on earth will be blessed through you." (Genesis 12:3, NLT). This is backed by the fact that Jews have received 100 times more Nobel prizes than the rest of humanity and that their religious thought animates the Abrahamic Sacred Texts of half of humanity.

However, there is no Nobel Prize destined yet to uncover the wisdom in Abraham's rigidity to obey God's order to sacrifice his only son (under the spell of the $1^{\text {st }}$ attention) and of his flexibility to sacrifice a lamb instead. I wonder if Jacob, the Third Patriarch, assumed that Abraham understood that context (for example, the voice of Gabriel and the $2^{\text {nd }}$ attention) invites flexible individuals to re-adjust the rigidity of any truth (under the will of the $3^{\text {rd }}$ Attention). Conversely, listening to a devilish $2^{\text {nd }}$ attention — the case of the young Jacob—would lead not to the $3^{\text {rd }}$ attention but to madness.

\subsection{The Deviousness of the Third Patriarch Jacob}

Jacob was a born trickster, since he had seized his twin brother Esau's ankle at birth. Genesis states that, by wearing a sheepskin jacket to feign that he was the hairy Esau, Jacob succeeded in obtaining Isaac's unique blessing that belonged to Esau; but this mind-twisted lad had to flee to the faraway whereabouts of his uncle Laban. Along his way, Jacob fell asleep at Bethel. While dreaming, he saw some angels going up and down a ramp that went from the earth to the sky. Upon understanding his dream, Jacob called the place in which he had fallen asleep "House of God".

Jacob's mysterious understanding of Divine Wisdom led him to offset the shrewdness of Laban. After 14 years of exploiting Jacob's talent, Laban made a deal with his son-in-law: Jacob would continue shepherding Laban's solid-white sheep and solid-black goats for free, while keeping their spotted descendants for himself. As he found ways to breed numerous robust spotted animals, Jacob amassed a sizable fortune. Six years later, he decided to move away his belongings; but Laban reached his son-in-law near Mount Gilead, the east of the Jordan River.

\footnotetext{
${ }^{8}$ For example, Massawa, located about 200 miles from Lake Tana.
} 
Having understood that Jacob had also enriched his house, Laban accepted God's advice to return home. Although the Third Patriarch Jacob avoided a bout with his father-in-law, he had to struggle for a night with a celestial envoy in the nearby Penuel. Upon confirming the fact that Jacob had 'walked-with-God' since Bethel, the Face-of-God changed his name to "Israel" ("he who wins with and is blessed by God" [Cassella, 2018c]). In the literature, the meaning of Israel's serendipitous blessing in Penuel remains as mysterious as the serendipitous story of his son Joseph.

\subsection{God Was with Joseph}

Although Joseph was never described as the Fourth Patriarch, his story is central to appreciate the ultimate meaning of Genesis, of Jacob's struggle at Penuel, and of the Ark of the Covenant built by Moses. In Canaan, Joseph's half-brothers sold him secretly into slavery. Because 'the Lord was with Joseph', however, he ended up as an overseer in the house of the Egyptian Potiphar, the captain of Pharaoh's guard. Potiphar sent Joseph to prison after Potiphar's wife unjustly accused the young man of trying to rape her. After being in prison for some time, he interpreted the dreams of Pharaoh's cupbearer and of his baker: In three days Pharaoh would restore the Cupbearer to his office and hang the former baker.

The restored Cupbearer remembered Joseph when no sage in Egypt could explain Pharaoh's first dream of seven lean cows devouring seven fat cows and a subsequent dream in which seven withered ears of grain destroyed seven good ears. Brought into the presence of Pharaoh, Joseph explained to him God's design to give Egypt seven years of abundance followed by seven years of famine. Having grasped the meaning of Joseph's integration of the two dreams in a wise prediction, Pharaoh asked his officials, "Can we find anyone else like this man so obviously filled with the spirit of God?" (Genesis 41:38, NLT). There and then, Pharaoh named Joseph vice-pharaoh; and gave him the responsibility of choosing a way of life over the way of death that menaced Egypt. Joseph's success led to his reconciliation with his brothers and to the migration of all Jews into Egypt in the $19^{\text {th }}$ century BCE.

Perhaps 'God was with Joseph' and 'Joseph walked with God' because both supported the union of Egyptian with Jewish Wisdom. This union was achieved by Moses.

Figure 1 suggests that Moses, a Prince of Egypt prior to building the Ark of the Covenant for Jews that had been welcomed to Egypt by Joseph, perceived the role of the roots of creativity in recognizing and solving a crucial problem.

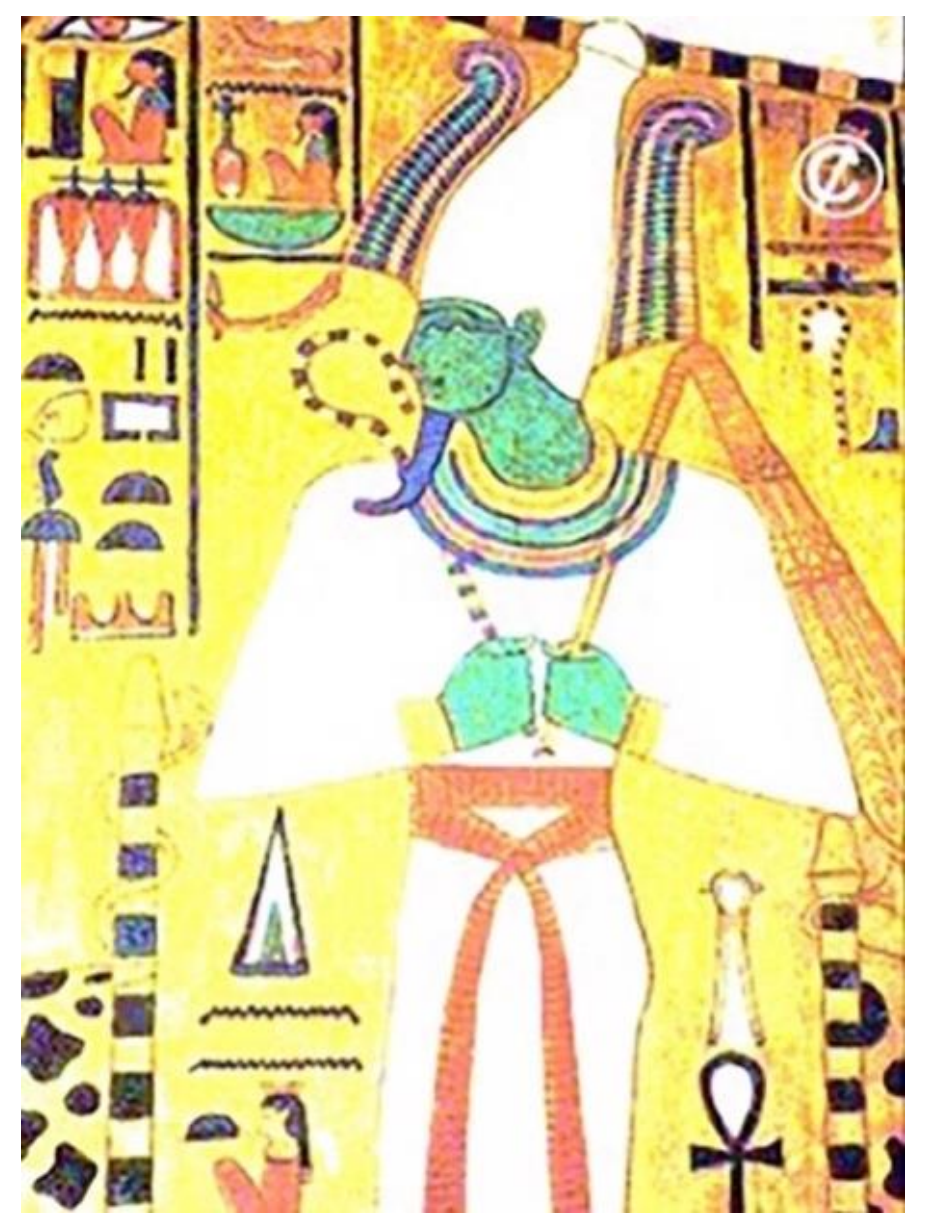

Figure 1. Osiris, the Crossing of the Crook and the Flail, the Triangle of Uniplurality, and the Ankh Cross 


\subsection{God Was with Moses}

Laws detailed in the Pentateuch are attributed to the work of Moses, one century before Pharaoh Akhenaten imposed his monotheistic views to Egyptians indifferent to the Union of repetitive perfection with uniplural less-than-perfection. Moses fits the role of a supreme prophet in all Abrahamic Sacred Texts. Perhaps the high valuation of Moses owes to the fact that there is more to Wisdom than the unvarying articles of a perfect law attached to Osiris' Crook and to the crystal Thummim. There is also the less-than-perfection of the Flail associated to the crystal Urim (Figure 2) and to problem-solving.

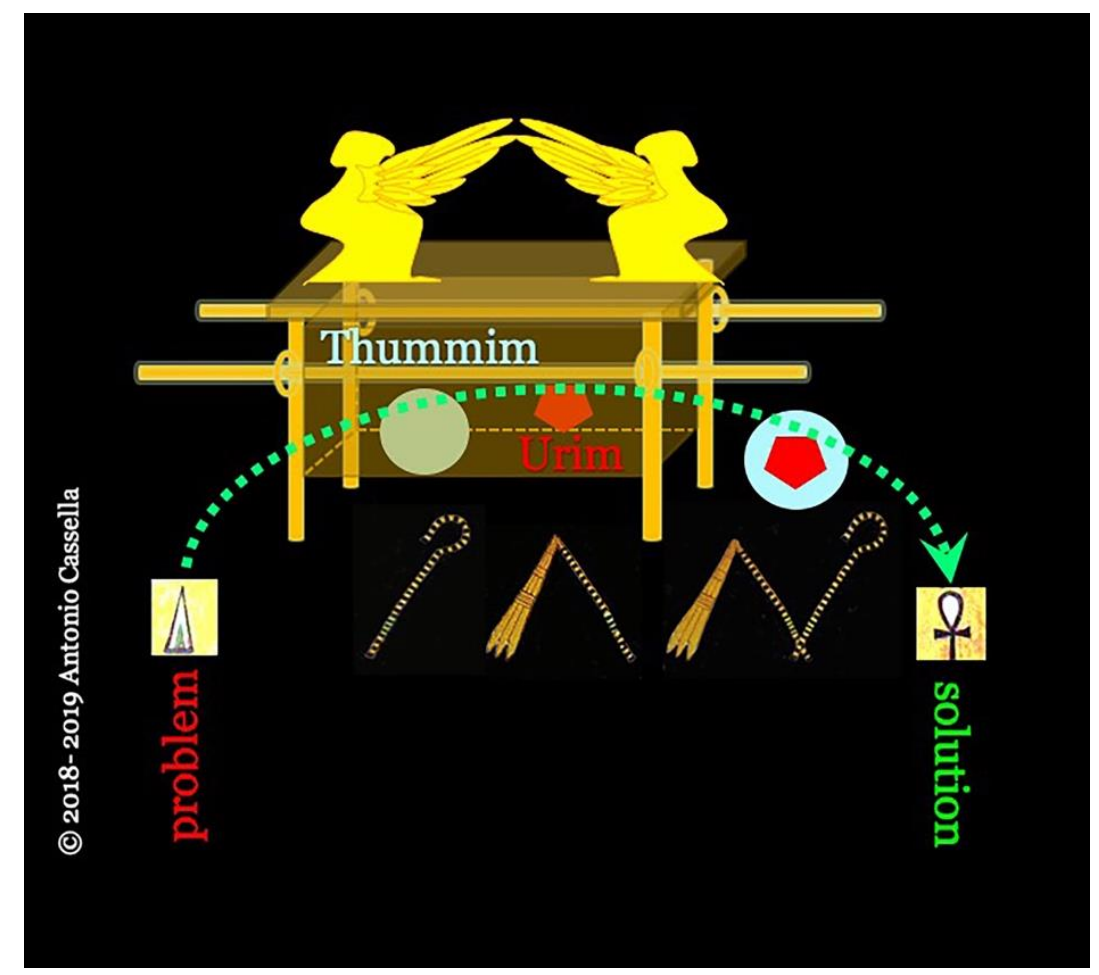

Figure 2. The Ark of the Covenant, the Thummim (the Crook), the Urim (the Flail), and their crossing

\subsection{God Was with Joseph Smith}

In the $19^{\text {th }}$ century CE, 33 centuries after Moses placed the precious stones Thummim and Urim in the Ark, Joseph Smith found them in America. Joseph Smith understood that the Union of the crystals Urim and Thummim (at the right in Figure 2) represents the nature of God. Indeed, a verse (D\&C, 130:6-11) offered in the book Doctrine and Alliances of Mormonism asserts that, "The place where God resides is a great Urim and Thummim."

Smith reported that he translated the ancient Book of Mormon with the help of the crystals Urim and Thummim, which he had received from the angel Moroni. Smith's implication that the Union of the two crystals makes up the Essence of God concurs with the warning issued by Zechariah in 580 BCE.

\subsection{The Two Staffs of Zechariah}

The prophet Zechariah wrote (Books 11-13) (Katznelson, 1991) "I took for myself two staffs (11:07); one I called No'am and the other Hovalim . . . And I took my staff No'am and cut it in two to revoke the covenant that I had celebrated with all nations (11:10). Later, I cut in two my other staff, Hovalim, so as to break the brotherhood between Judah and Israel (11:14) . . . Wake up, oh my sword, against my shepherd and against the man nearer to me, says the Eternal. Hurt the shepherd and the sheep will scatter; and I will turn my hand on the young (13:07) . . Two parts of all Earth will die, but the third one will last" (13:08).

In order to understand Zechariah's purpose to protect our children from chaos, we should pair the flexible covenant of the staff "No'am" with the crystal "Urim"; and the brotherly rigidity of the staff "Hovalim," with the crystal "Thummim." This initiative warrants the interpretation of three fragments (Cappelletti, 1972) about the Logos of the Ionian-Greek philosopher Heraclitus.

\footnotetext{
9 Translation by the author.
} 


\subsection{Logos and Nature's Nature from 3 fragments of Heraclitus from Ephesus}

In fragment 2 (Cappelletti, 1972, p. 64) ${ }^{10}$, Heraclitus asserts that “. . . it is necessary to embrace the impartial, or the common." He points to the $1^{\text {st }}$ attention, Moses' Thummim, or Zechariah's Hovalim. In fragment 10 (Cappelletti, 1972, p. 68), ${ }^{11}$ Heraclitus states "From all things, the one; and from the one, all things." His view can be matched with the uniplurality inherent in the $2^{\text {nd }}$ attention, the crystal Urim, and the staff No'am.

As Harry Potter (Cassella, 2018c) crosses a brick wall in London's King's Cross Station (Rowling, 1997) and the resurrected Christ enters the locked house of his frightened disciples (John, 20:19-25), different objects can share the same space at the same time ("from all things, the one"), which is in line with quantum superposition (Icke, 1995). Similarly, when Harry Potter secretly observes his past self (Rowling, 1999), he suggests that one object can exist in more than one place ("and from the one, all things"), as in quantum entanglement (Feynman, 1985).

Finally, fragment 59 of Heraclitus (Cappelletti 1972, p. 94), "In a weaving device, the straight path (the crystal Thummim or the staff Hovalim) and the curved path (the crystal Urim or the staff No'am) become one and the same,"12 reflects the Union of Thummim with Urim, Hovalim with No'am, or the rainbow after a tempest. Taken together, fragments 2, 10, and 59 of Heraclitus' Logos point at Moses' and Solomon's Wisdom.

\subsection{The Logos Heuristics}

In this subsection, I will recount how the comparison of autistic with nonautistic subjects allowed me to build the principles of the logos heuristics (Figure 3).

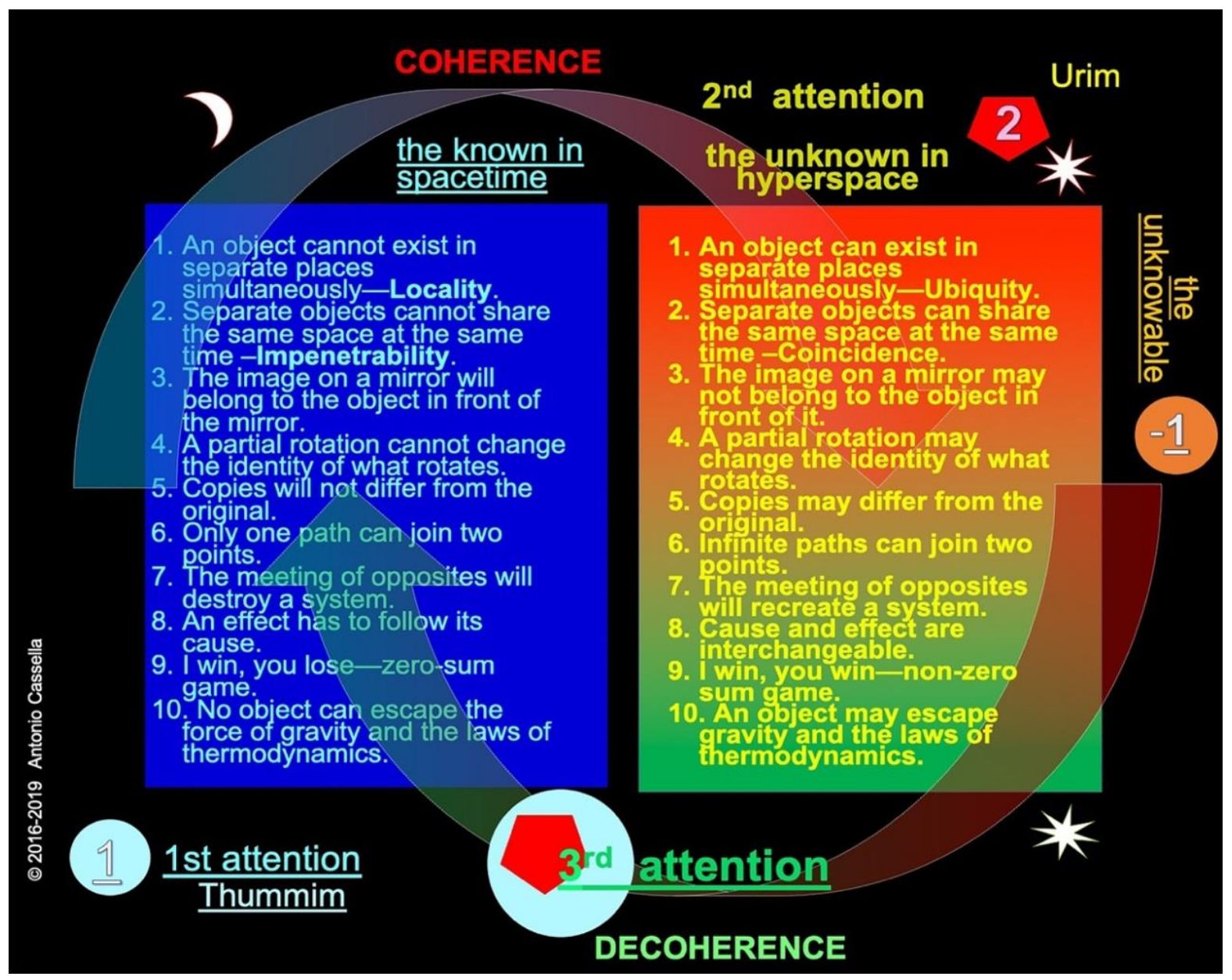

Figure 3. The play of the principles of spacetime and the principles of hyperspace

In the summer of 1996, I examined the capacity of 16 autistic and two nonautistic subjects for passing a battery of neuropsychological tests (Cassella, 1997, 2000, 2002). The tests included the capacity to link true representations of the

\footnotetext{
10 Translation by the author.

11 Ditto.

12 Ditto.
} 
self (classical meta-representation in spacetime) through the Proper-Self protocol (Povinelli, Landau, and Perilloux [1996]). They also included the capacity for passing two false-belief tasks (Baron-Cohen, 1995) by choosing a false over a true representation (quantum meta-representation in hyperspace). All the high-functioning autistics of my sample passed Proper Self - a test about the meta-representational continuity of the self through time. The latter result agrees with Perner's (1991) finding that high-functioning autistics pass Zaitchik Photo Test (Zaitchik, 1990), a measure of the meta-representational capacity to appreciate the continuity of the other through time. The results also corroborated the conclusion of Baron-Cohen that able autistics do not pass meta-representational false-belief tasks. My research allowed me to stress that autistics will not pass tests based on the principles of hyperspace, which are detailed in Figure 3. ${ }^{13}$

I proposed (Cassella, 1997, 2000, 2002) that the quantum hyperspace impaired in autism is centered in the belief that the same object can exist in two or more places at the same time (Ubiquity) and that two or more objects can share the same space at the same time (Coincidence). Within spacetime, the principle of Locality posits that no object can exist in two or more places simultaneously; and the principle of Impenetrability, that two or more objects cannot share the same space at the same time. The creative Play of spacetime and hyperspace, rigidity and flexibility, classical and quantum computing, Thummim and Urim, or Hovalim and No'am makes the logos heuristics (or $\Lambda$ ).

The logos heuristics implies that the inability of autistics to handle joint attention, pretend play, false-belief tasks, irony, metaphor, the proper use of pronouns, riddles, polyvalent signs, and the design of rules divorced from shared tradition obeys the fact that autistics cannot suspend the logical principles of mental spacetime while they imagine new ideas through the absurd principles of mental hyperspace.

I attribute classical computing in spacetime to the $1^{\text {st }}$ attention; quantum computing in hyperspace, to the $2^{\text {nd }}$ attention; and their Reciprocal Empowerment, to the $3^{\text {rd }}$ Attention.

In the 'Discussion', I will use the logos heuristics to interpret the ways of Kong-Fuzi (Confucius) and Laozi (Lao Tzu, as "Old Master"). I will also focus the discussion on the $3^{\text {rd }}$ Attention in the discourse followed by Lord Khrishna and Arjuna in the Bhagavad Gita, the verses of Vālmīki's Rāmāyana, the Maya Sacred Text Popol Vuh, and the Mesoamerican myth of the return of a creative flying-serpent, or "Quetzal-coatl" to the Mexica-Aztecs.

\section{Discussion}

\subsection{The Way of Kong-Fuzi in the First Attention and the Way of Laozi in the Second Attention}

After reasoning that no one could leave a house without using the door, Kong-Fuzi worried why his contemporaries did not follow his 'way-of-reason' (Analects, 6.17) (Kong-Fuzi, 1995). Because Kong-Fuzi exalted order over chaos, he could not value the principle of Coincidence in which different objects share the same space at the same time. Hence, I propose to attach the unbending rigor of Kong-Fuzi's reason to the $1^{\text {st }}$ attention, Zechariah's Hovalim, the crystal Thummim, and Osiris' Crook.

This differs from the Tao (Way) intended by Laozi (Old-Master), a sage seemingly older than Kong-Fuzi. In the mythical encounter of the two sages, Kong-Fuzi may have heard the following words from Laozi, "Unbending rigor is the mate of death, and yielding softness, the company of life." (Lao Tze, 1891.) Following the logos heuristics, I attach the yielding softness of Laozi to the $2^{\text {nd }}$ attention, Zechariah's No'am, the crystal Urim, and Osiris' Flail.

The loss of yielding softness in autistics supports the separation of the 'rigidity of Kong-Fuzi' from the 'flexibility praised by Laozi'. Moreover, the mythical encounter of the two sages implies that Social Intelligence and true Wisdom rest on integrating Kong-Fuzi's Analects with Laozi's Tao Te Ching. This integration was quietly achieved by the Buddha and by his disciple Mahākāśyapa beyond meditation.

\subsection{The Middle Way of the Buddha in Alignment with the Third Attention}

The Buddha gave himself the name "Tathāgatha," which can be interpreted as "one-who-has-thus-gone" ("Tathā-gatha"), "One-who-has-thus-come" ("Tathā-āgatha"), or "One-who-has-thus-come-and-gone." The $3^{\text {rd }}$ interpretation, one attached to 'Going-and-returning-simultaneously', highlights both the infinite speed of the $2^{\text {nd }}$ attention and the $3^{\text {rd }}$ Attention of the Buddha, when he decided to save others from the madness induced by narcissism and personal ambition.

The latter interpretation touches also the role of any "Bodhisattva," who returns to the world of finiteness of the $1^{\text {st }}$ attention in order to help others grasp infinity in the ambiguous tension of the $2^{\text {nd }}$ attention and the contentment of the $3^{\text {rd }}$ Attention.

Mahākāśyapa, a brilliant Bodhisattva treasured by the Buddha, laughed when his master displayed a lotus flower in a silent sermon. Assigning spontaneous laughing to the $3^{\text {rd }}$ Attention justifies the interpretation that

13 All the sets shown in Figure 3 can be deducted from the first two sets (Cassella, 2002). 
a) Mahākāśyapa too had reached the $3^{\text {rd }}$ attention beyond meditation, although

b) the aim of meditation is joining in the mind/brain the $1^{\text {st }}$ attention attached to the masculine "Yang" with the $2^{\text {nd }}$ attention inherent in the feminine "Yin."

In our 'mind/brain-Ark-of-the-Covenant', meditation reinforces first our focused attention, classical computing, our masculine-cerebral Yang, and the crystal Thummim. Within mindfullness, our brain embraces our cerebellar-feminine Yin, quantum coherence, the ability to go into two or more places at the same time or to become nothing, and the crystal Urim. Finally, loving-kindness follows the decoherence that joins our male Yang with our female Yin (Chapter 63 in Cassella, 2018c) in the social mind that smiles to others in wishing the best to them.

Wishing the best to others - in helping them suspend the conflicts attached to the $1^{\text {st }}$ attention, enter the doubt of the $2^{\text {nd }}$ attention, and win with their enemies a better world for all-favors the rise of the $3^{\text {rd }}$ Attention in any individual and in any reader of the discourse between Khrishna and Arjuna in the Bhagavad Gìtā.

\subsection{The Way of Khrishna and Arjuna in the Bhagavad Gìtā;}

At the beginning of the Bhagavad Gìtā, Arjuna asks Lord Krishna "Of what avail to us are a kingdom, enjoyment, or even life itself when those for whom we may desire all happiness are now arrayed on this battlefield?" (Baktivedanta, 1972-1983, p. 51).

Arjuna's friends and relatives confront each other within the $1^{\text {st }}$ attention. The Supreme Archer Arjuna tries to dispel his grief with the help of Lord Khrishna. Krishna's final answer in the Bhagavad Gïtä is, "That which in the beginning may be like poison, in the end is just like nectar that awakens one to self-realization . . . happiness . . . and goodness" (Baktivedanta 1972-1983, p. 640). Krishna's words suggest that most solutions to a problem are found at the edge of madness. This would explain why the inability of autistics to embrace order and chaos simultaneously hampers them from facing the dilemmas produced by unforeseeable change.

Arjuna, Krishna, and the Bhagavad Gìtā show that both the conservation of order attached to Vishnu as an avatar of the $1^{\text {st }}$ attention and the destruction of order attributed to Shiva as an avatar of the $2^{\text {nd }}$ attention may unite in the effort to find a new world in which both the self and the other may thrive. This effort contributes to the shining Wisdom of Brahman in the domain of the $3^{\text {rd }}$ Attention.

\subsection{The Way of the Ramayana}

The search for the $3^{\text {rd }}$ Attention shines also in the Rāmāyana, a text written in the $5^{\text {th }}$ century BCE by the sage Vālmīki ( $5^{\text {th }}$ century BCE-2018). This text illustrates the efforts of King Rama to save his wife Sita from the temptations, illegitimate designs, tricks, and reproachable actions performed by the abominable Ravana.

Sita echoes the valuable quantum aid that comes up when a warrior (for example, Rama) follows the fair use of the second attention, whereas the ghastly Ravana represents the vicious use of the $2^{\text {nd }}$ attention. Thus, saving Sita by bringing her back to his palace, and even killing Ravana, should lead Rama into reaching the $3^{\text {rd }}$ Attention. However, Rama forces Sita to go through a test of fire, which she passes, to the chagrin of gossipers.

By bending to the gossip of the flock that Rama retains through the power of obedience exacted by the $1^{\text {st }}$ attention, however, the ambition of that king condemns the heroic Sita to a shameful exile. The pregnant Sita finds refuge in the dwelling of Vālmīki ( $5^{\text {th }}$ century BCE-2018), the writer of the Ramayana. It would seem, then, that Vālmīki thought that only sages who reach the $3^{\text {rd }}$ Attention can understand the virtuous use of the $2^{\text {nd }}$ attention, an opportunity lost by Rama. An additional implication is that his mistreatment of Sita (a metaphor for the discerning quality of quantum computing) will separate Rama from the $3^{\text {rd }}$ Attention.

Hawaiian sages would say that Rama abandons his "mana" (that is, Sita or the $2^{\text {nd }}$ attention) in life. I cannot say whether the possibility of using the $2^{\text {nd }}$ attention to reach the $3^{\text {rd }}$ Attention met the Wisdom of Mesoamerican Olmecs from China through Hawaii and the Pacific or crossed the Atlantic from the Cape of Good Hope.

\subsection{Resurrection in the Popol Vuh}

The Olmecs, who thrived in the first millennium BCE, passed to the Maya the myth of a creative 'flying-serpent'. The Nahuatl-speaking Mexicas followed descriptions conceptualized by the Maya in calling later that plumed-snake "Quetzal-coatl." Although the Mayan Text Popol Vuh (Anonymous, 2003) accepts the initial intervention of a flying serpent in the creation of the world, the heroes of that narrative are the twins Xbalanqué and Hunahpú. Their mythical story reflects the human power to re-create the world, exemplified by the legendary journey of Quetzalcoatl to Venus with the Morning Star and by his return to Earth with the Evening Star.

At first sight it would seem that the separation between the Morning and the Evening Star implies only a finite speed, a repetitive time sequence, and the first attention. However, the capacity of Xbalanqué and Hunahpú for coming back 
from death suggests that the writers of the Popol Vuh attributed life-giving creativity to the alliance of finite with infinite speed in the world of the $3^{\text {rd }}$ attention.

The twins grew up as champions of ball playing and were invited by the Lords of the Xibalbá — the Mayan Hell—to play in the same court where their father and uncle died. The invitation is a ruse, since the twins would die if they won. Although they can resurrect themselves and others, Xbalanqué and Hunahpú are aware of the trick and lose every game. In the end, after their decision to win a game, they are burnt and grounded to dust by the Lords of the Xibalbá. However, Xbalanqué and Hunahpú come back as a pair of unrelated boys. In their new semblances, they show the Lords of the Xibalbá how the animals and the people they kill return to life. Upon seeing that miracle, the diabolical Lords of the Xibalbá ask for their own death and resurrection. However, after they die, their resurrection does not happen.

The resurrections performed by Xbalanqué and Hunahpú could be ascribed to the power of the $2^{\text {nd }}$ attention to suspend the three laws of Thermodynamics, in agreement with the principles of hyperspace shown in Figure 3. However, the imaginative fact that the twins resurrect to favor justice, while the Lords of the Xibalbá do not, suggests that Xbalanqué and Hunahpú also master quantum decoherence and the $3^{\text {rd }}$ Attention. Although they manage quantum coherence, the unkind Lords of the Xibalbá cannot return to a new life through quantum decoherence because they cannot repent. Similarly, Quetzalcoatl will return only if he changes from a devil into a Saint (Cassella, 2018d). (We too should repent in order to save our young.)

\subsection{The Myth of the Return of Quetzalcoatl}

Quetzalcoatl symbolizes both a flying serpent in the $2^{\text {nd }}$ attention and the eventual return of the $3^{\text {rd }}$ Attention in any repented human being, any society, and global civilization. Figure 4 offers a graphical representation of that desirable feat.

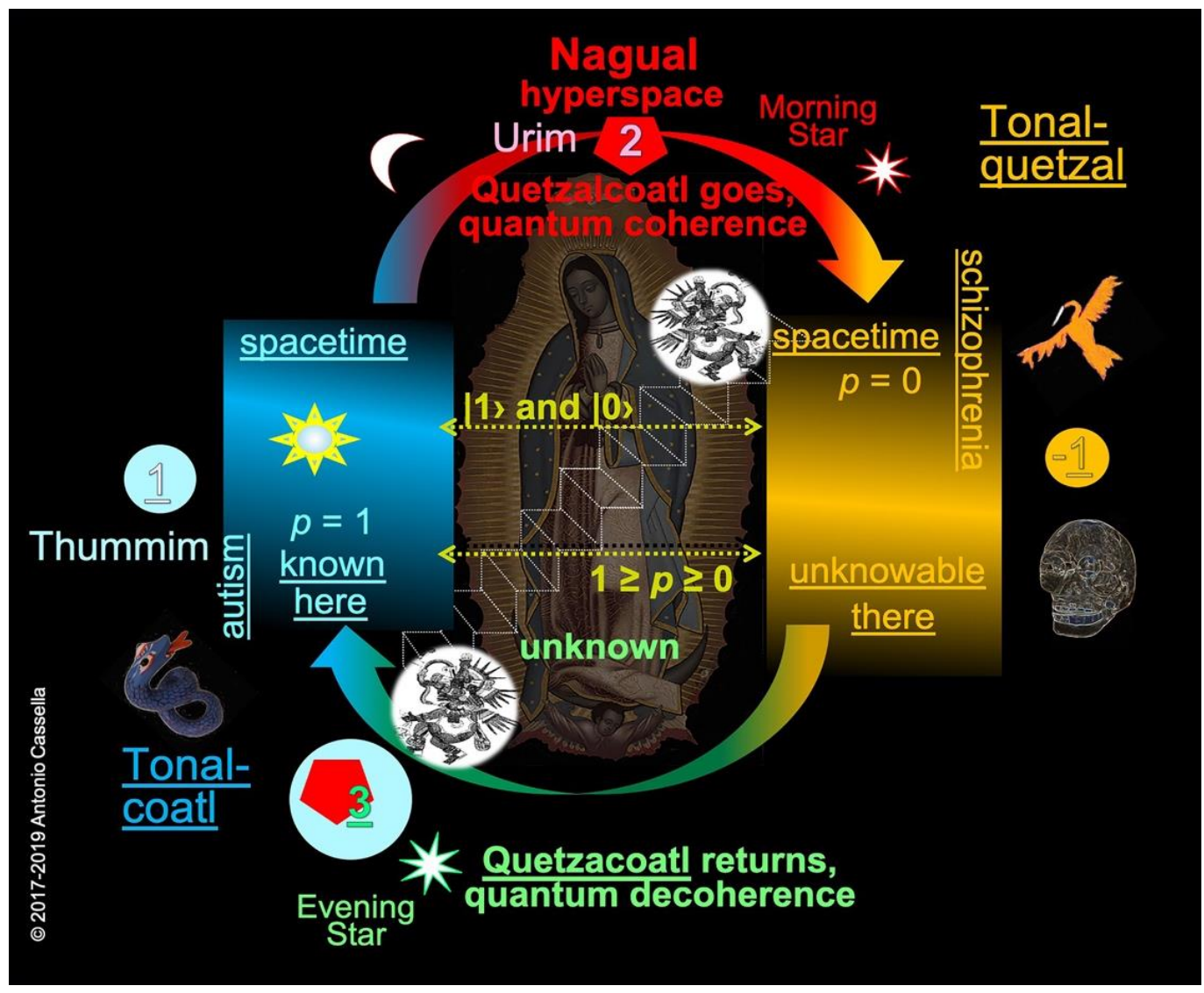

Figure 4. The journey of Quetzalcoatl from spacetime (1), through hyperspace (2), into a renewed spacetime (3)

The word "quetzal" stands for "bird" and "Sky," whereas the word "coatl" stands for "serpent" and "Earth." Before the age of three years, autistics lose the capacity to exist in the domain of knowledge that stands between the Earth and the Sky - hyperspace, or the world of the $2^{\text {nd }}$ attention located between autistic obedience and schizophrenic disobedience.

Although some autistics become at times disruptive and disobedient, they cannot embrace good and evil simultaneously, or change into a "coatl-quetzal." Similarly, normal human beings that could grab the fruit of the 
tree-of-the-knowledge-of-good-and-evil in childhood lose the potential to become a returning "quetzal-coatl" by eating the fruit of the Tree-of-Life in adulthood. Schizophrenics, for example, validate Fragment 2 of Heraclitus, since they cannot re-create a shared "impartial-common" with their companions. In essence, 'autistics cannot go'; and 'schizophrenics cannot return'. Brain-washed zombies may believe in returning. In my view, however, no one can!

In the work Journey to Ixtlán (Castaneda, 1972), Don Genaro tells Carlos Castaneda that he could never return to his home town, Ixtlán. His words do not imply that he is mad. Simply put, we must believe simultaneously in the reality of an unchanging Ixtlán, in our free decision to abandon it, and in our capacity to wake up in a new "Ixtlán," or the $3^{\text {rd }}$ Attention.

In Mesoamerican legends (Figure 4), Quetzalcoatl followed the Moon and the Morning Star in exploring the principles of the $2^{\text {nd }}$ attention, hyperspace, the crystal Urim, or the Nagual. Before going, Quetzalcoatl is only the Tonal, or the crystal Thummim. He (or she) may return to Earth with the Evening Star only if he (or she) acquires the $3^{\text {rd }}$ Attention, in which the quantum "Nagual" and the classical "Tonal" coalesce into the quantum-classical "Eagle." The myth of Quetzalcoatl and the Mexican "Eagle-with-a-serpent" could be considered a metaphor for our need to balance the principles of classical computing with the principles of quantum computing, as did Jacob after his dream in Bethel. Furthermore, the unselfish Virgin of Guadalupe (Figure 4) suggests that we can use quantum computing to grow with others. Growing with others, however, precludes our return to Ixtlán, as Don Genaro tries to tell Castaneda.

\subsection{The Unselfish Use of Quantum Computing}

Every culture reveres an unrecognized symbol of the caring use of quantum computing. These include for example, the Virgin Mary in Catholic, Anglican, and Orthodox Churches, the Holy Ghost in Protestant Churches, the angel Gabriel in Islam, the goddess Saraswati in India, and the Bodhisattva Guanyin in China. All Sacred Texts show that we abandon Ixtlán forever in helping others grow. Figure 5 shows that one's own Sacred Text offers the best door (1) to cross the labyrinth of the $2^{\text {nd }}$ attention (2), avoid madness (-1), and reach the Progress promised by the $3^{\text {rd }}$ Attention (3).

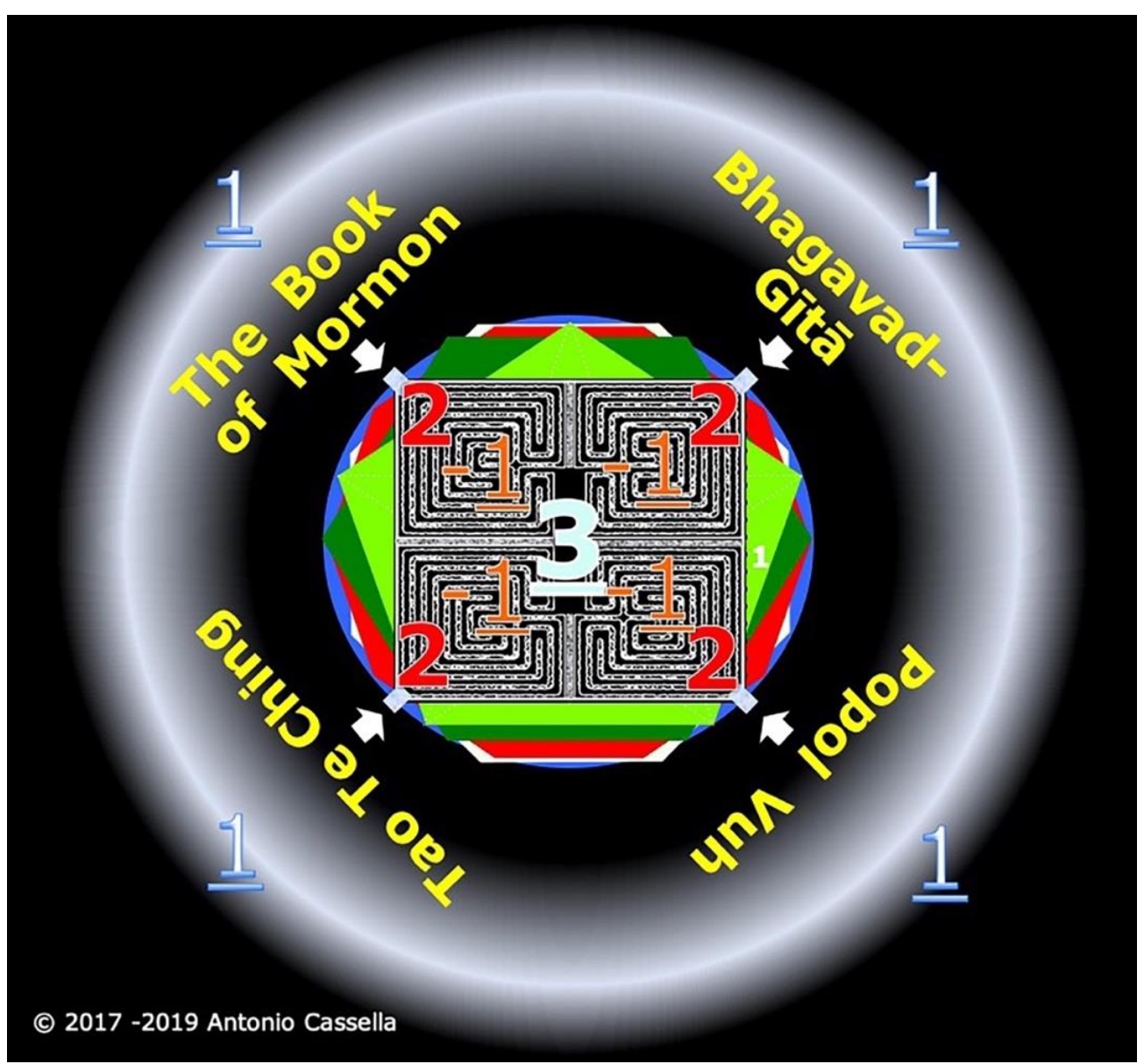

Figure 5. Any Sacred Text may lead its readers to the $3^{\text {rd }}$ Attention

Knowledge of the importance of having one's own Sacred Text at hand may have moved King Solomon in the $10^{\text {th }}$ century BCE to influence the esoteric meaning of the religious oral tradition of the Jewish people. By doing this, he 
mastered the meaning of the Thummim and Urim crystals in the Ark and the Wisdom hidden in their Union.

\subsection{The Wisdom of King Solomon}

The Book of Kings (3:16) teaches that King Solomon was asked to decide which between two mothers, was telling the truth. Both women had gone to sleep with their babies on the same bed. During the night, one baby died; and the next day, each mother claimed the surviving baby. Solomon asked one of his guards to cut the baby in two and give one half to each mother. At that point, one of the two women asked Solomon to give the baby to her opponent in order to save his life. Her act showed Solomon that she was the true mother; and he gave the baby to her.

The true mother lied when she recognized the legal right of her contender. Solomon also lied when he asked for cutting the baby in two. Although they lied within the $2^{\text {nd }}$ attention, the desire to help others led Solomon and the true mother to land into their $3^{\text {rd }}$ Attention. If we study the feats of King Solomon, we will conclude that he disrespected the entire ten Commandments. And yet, his Wit came from God.

The Queen of Sheba explored Solomon's Wisdom by flooding him with riddles. One example was to identify what does not move when it is alive but moves after its death. Solomon may have told Sheba that trees cannot move while they are alive; but move swiftly through the oceans when they are cut into a ship. Of course, Sheba knew the solution as firmly as she knew that we will keep our ability to smile spontaneously as long as we do not cut the Tree-of-Life. However, we are doing that through the 'global warming' that will dampen the smile of our grandchildren.

\subsection{Smiling and the Face of God}

Figure 6 gives my graphical view (Cassella, 2018b) of the neurocircuitry behind the spontaneous smile that follows our understanding of the meaning of a pun, akin to the solution that may follow our decision to overcome a crucial problem.

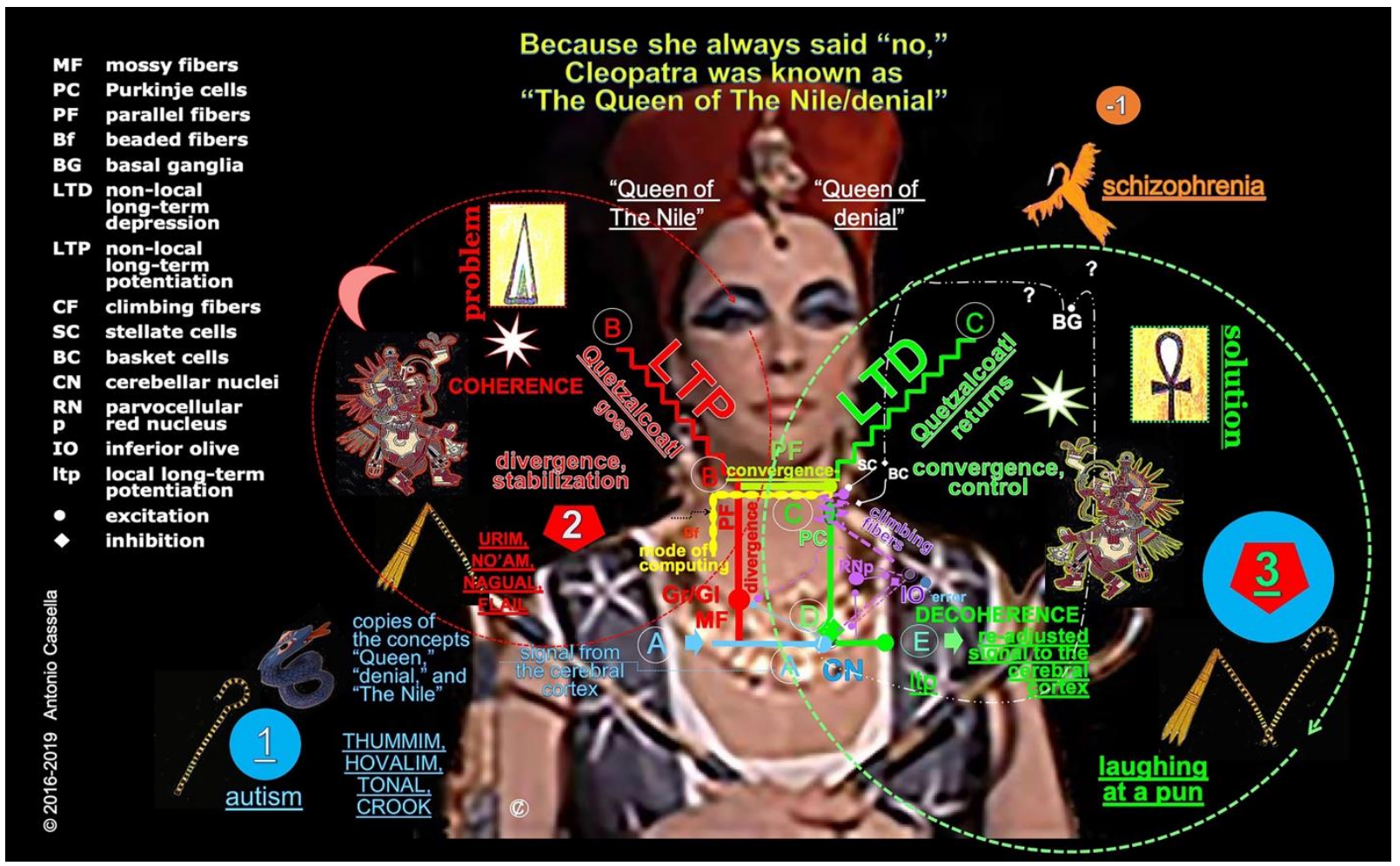

Figure 6. Cleopatra and the neurocircuitry of a smile ${ }^{14}$

Through Solomon's Wisdom, the Queen of Sheba understood that eating the apple of quantum computing within the crystal Urim - a feat prohibited by the law enclosed in the crystal Thummim - is a necessary and yet insufficient condition to grab the fruit of the Tree-of-Life protected by God's Wisdom. We can grab the fruit of the Tree-of-Life only if we lie for a good reason!

As with the return of Quetzalcoatl, the Tree-of-Life implies joining the Crook to the Flail, Thummim to Urim, Hovalim to No'am, and the Tonal to the Nagual. Any spontaneous smile reflects the capacity to join the $1^{\text {st }}$ to the $2^{\text {nd }}$ attention within a generous and amusing purpose. A genuine smile (Figure 6) signals our crossing through cerebellar decoherence,

${ }^{14}$ See also Ito (2011). 
toward the cerebral illusion that an unchanging Ixtlán is waiting out there.

In line with the hypothesis that the brain of any human being echoes the Garden of Eden, our cerebral cortex hosts the invariant memories that make the impartial frame of knowledge protected by classical computing and the autistic side of the mind (Cassella, 2018b). As shown in Figure 6, Long-Term-Potentiation (LTP) makes the tree-of-the-knowledge-of-good-and-evil sought by our diabolical mind, whereas Long-Term-Depression (LTD) leads us to the Tree-of-Life sought by our social mind. Beautiful churches in the Islamic and Christian faiths prove that LTP and LTD may unite in the heavenly splendor that surrounds life-giving creativity.

Science cannot measure the Union of LTP and LTD (Ito, 1993); for example, no scientist could have joined Michelangelo in predicting what had to go to transform a block of marble into his 'Pietà' 15

The autistic facet of the mind (the $1^{\text {st }}$ attention, or the crystal Thummim) guided by classical neural computing makes a necessary and yet insufficient condition to understand a masterpiece, a Sacred Text, or a pun-for instance, about Cleopatra. Engaging our artistic facet (the $2^{\text {nd }}$ attention, the crystal Urim, or the quantum coherence initiated by LTP) is also necessary and insufficient. In inviting us to smile after understanding a pun, our cerebellar microcomplexes lead us out of LTP and of psychosis into the LTD attached to quantum decoherence.

The Face-of-God, Gabriel, Shekinah, the Great Mother, or the Holy Spirit walks with whoever uses LTP and quantum coherence in the crystal Urim to split copies of relevant Thummim-memories into the Purkinje cells of cerebellar microcomplexes. Amazingly, the humorous Thummim-and-Urim-self 'walks with God' in the LTD of quantum decoherence, conjured up in the Purkinje cells that continue inhibiting the deep cerebellar nuclei of our 5000 microcomplexes in re-adjusting with a smile the humorous reality that escapes psychotics.

I consider that our remote ancestors knew about the Wisdom of the universal play of LTP with LTD in a smile.

\subsection{The Mysterious Crossing of Gorham's Cave}

Figure 7 postulates a graphical account of the journey of Wisdom.

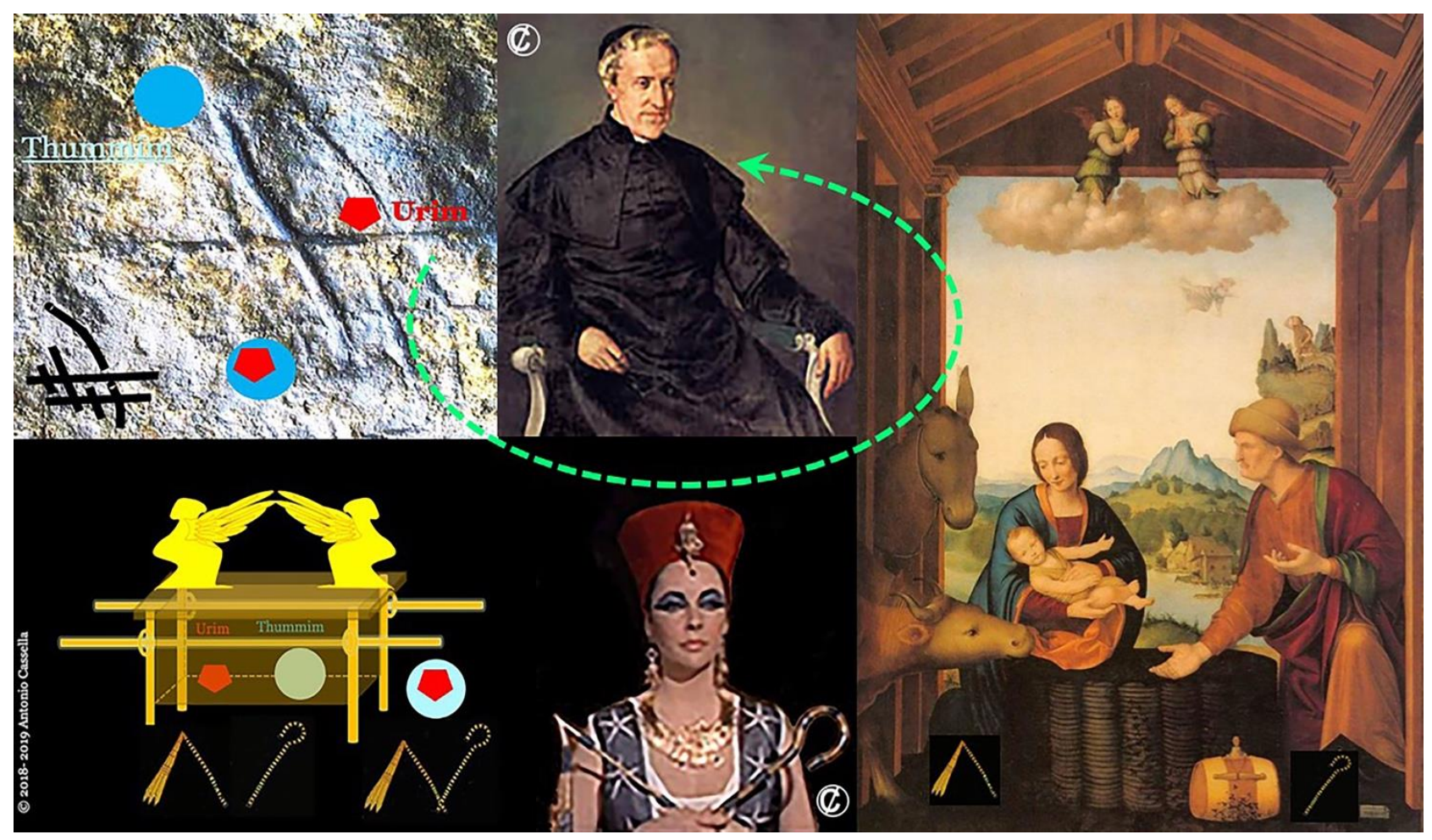

Figure 7. From the Crossing left in Gorham's Cave to the thought of Antonio Rosmini ${ }^{16}$

Rodríguez-Vidal et al. (2014) reported the preservation of a Crossing (upper left corner) left around $38000 \mathrm{BCE}$ in Gorham's Cave, now at the edge of the sea in Gibraltar. ${ }^{17}$

\footnotetext{
15 Ito's comment to me in 2013.

16 Gorham's Crossing and the Nativity Scene are reproduced with the authorization of the owners of the inherent copyright.

17 See also Cassella (2018c).
} 
My interpretation of Gorham's Crossing (Cassella, 2016, 2018c, 2018e) assumes that:

1. the deepest vertical tracing that crosses the two horizontal lines represents the repetitiveness of classical computing, the $1^{\text {st }}$ attention, the Crook, the crystal Thummim, Zechariah's Hovalim, and the Aztec Tonal;

2. the upper horizontal line represents the $2^{\text {nd }}$ attention, the tension introduced by quantum coherence in the string of a guitar, the Flail, the crystal Urim, Zechariah's No'am, and the Aztec Nagual; and

3. the lower horizontal line represents quantum decoherence; for example, Francisco Tarrega's Recuerdos de la Alhambra played by Andrés Segovia.

Within decoherence, the $3^{\text {rd }}$ Attention releases the tension of coherence into the beauty of the Union of Thummim with Urim, Hovalim with No'am, the Crook with the Flail, o the Tonal with the Nagual. Possibly, the artist of Gorham's Cave reached Africa; his or her descendants, Egypt; and even America by virtue of the Ark built by Moses, the Wisdom that God gave Solomon, Sheba's will, and American wit.

\subsection{The Ark of the Covenant and the Last Pharaoh Cleopatra VII}

Gorham's Crossing may have supported the Crossing of the Crook with the Flail on the chest of Osiris/Horus/Pharaoh; and of the crystals Thummim and Urim on the vest that Aaron kept in the Ark of the Covenant. I reiterate that, as an educated Prince of Egypt, Moses knew from Thoth of the importance of Crossing the rigidity of the Crook-Thummim with the flexibility of the Flail-Urim. Fifteen centuries after Moses, the last pharaoh Queen Cleopatra VII did not!

Although she crossed the Crook and the Flail on her chest, Cleopatra (center-bottom of Figure 7) had to leave behind forever her Isis, Osiris, and Horus selves on August 12 of the year 30 BCE. Had the last Pharaoh known about the balance of the principles behind that Crossing, her lover Marcus-Antonius - and not her enemy Octavianus-Augustus - would have made the first Roman Emperor and the $8^{\text {th }}$ month of the year.

\subsection{Leonardo's Nativity}

Leonardo da Vinci hid the meaning of the Crossing of rigidity-Thummim with flexibility-Urim in all his paintings. As I wrote before (Cassella, 2016, 2018c, 2018d, 2018e), the Nativity Scene pictured at the right of Figure 7 was painted by Leonardo before the end of the $15^{\text {th }}$ century CE. This unknown work is kept in the Church of "Santa Maria dei Canali" at Tortona, south of Milan (Italy).

Leonardo's Nativity hides the principles of Coincidence and Ubiquity in the two angels that bless any family on Earth: Without the two angels, the cloud would stay definitely outside the manger; and without the cloud, the two angels would stay only inside the stable. In that painting, Saint Joseph stands for the crystal Thummim and the $1^{\text {st }}$ Attention; the Virgin Mary stands for the gracious use of quantum computing in the $2^{\text {nd }}$ attention; and little Jesus, for the $3^{\text {rd }}$ Attention.

The two angels look at Mary because the three entities work together. The grace of Mary, in using quantum computing to help others, explains why Antonio Rosmini freed the repented sinners who wished to receive God's Blessing in the Sacrament of Confession.

\subsection{The Uniplurality of Antonio Rosmini}

In the first half of the $19^{\text {th }}$ century, Antonio Rosmini perceived the power of infinity/nothingness in uniplurality. The familiarity with Scholastic Philosophy must have helped him validate the hylomorphism proposed at the turn of the $13^{\text {th }}$ century CE by Saint Thomas Aquinas. Within the Catholic hylomorphism in the Transubstantiation consecrated in the Eucharist, a consecrated host sunk in wine becomes the body and blood of Christ. In the $16^{\text {th }}$ century CE, the Council of Trent agreed with Saint Thomas.

Although they are paradoxical, the Ubiquity and Coincidence hidden by Scholastic philosophers (in the like of Duns Scotus, William of Ockham, and Thomas Aquinas) in the question "how many angels (infinity) can dance on the tip (nothingness) of a pin (unity)?" do not respond to the thinking of a dunce. For example, dividing the unity by 10 gives 0.10 ; dividing the unity by 100 gives 0.01 ; and dividing any unity by an infinite number gives zero.

The Council of Trent, however, would not bless Martin Luther's Consubstantiation (the nothingness, Coincidence, or quantum superposition by which two things can share the same space at the same time), or his perception of Christ's omnipresence (the infinite speed, Ubiquity, or quantum entanglement, by which the same person can exist simultaneously in the words "The Nile" and "denial"). And yet, Luther's infinity and nothingness underlie the smile that appears on our faces when we hear a pun, when we solve a riddle, and when we appreciate a new piece of knowledge.

Antonio Rosmini understood that the uniplural Communion of the principles of quantum computing with the principles of classical computing explains the Divine, any journey of the human mind, and Progress. For example, in the Catholic concept of the Trinity validated by the Council of Trent, the 'one that is simultaneously many' supports Ubiquity and 
the 'many that are simultaneously one' support Coincidence. Thus, the belief that the Father is simultaneously the Son and the Holy Spirit implies the relationship among unity, nothingness, and infinity envisioned by Luther, Duns Scotus, William of Ockham, and Thomas Aquinas. That said, no one ever matched the Trinity to our three attentions, although Luke the Evangelist implied that Christ mastered the $3^{\text {rd }}$ Attention.

In the early $19^{\text {th }}$ century, Rosmini headed the Church of Saint Mark in Rovereto (Trento, Italy) for 1.5 years. He must have dealt with the story reported by Luke $(4,21-30$, NLT) in which Jesus reproached the faithful of a synagogue. They ". . . took him to the brow of the hill on which the town was built, in order to throw him off the cliff. But he walked right through the crowd and went on his way."

Rosmini must have recognized that the change of mind in the people of Nazareth that let Jesus go matched His ability to use the nothingness of the principle of Coincidence to cross the bodies of the same people that had tried to push Him into a precipice. Whatever interpretation we may choose, Luke's account implies that Jesus did perform a miracle by showing to his concitizens the value of the nothingness that precedes Progress.

\subsection{Social Values}

Figure 8 relates unity, infinity, and nothingness in the crystals Thummim and Urim (the Crook and the Flail, Hovalim and No'am, the Tonal and the Nagual) to their Crossing in social values. As with Jacob, readers of Sacred Texts may use the logos heuristics to walk the way of hunting of the $1^{\text {st }}$ attention, the way of war of the $2^{\text {nd }}$ attention, and the way of Progress of the $3^{\text {rd }}$ Attention (Cassella, 2018c).

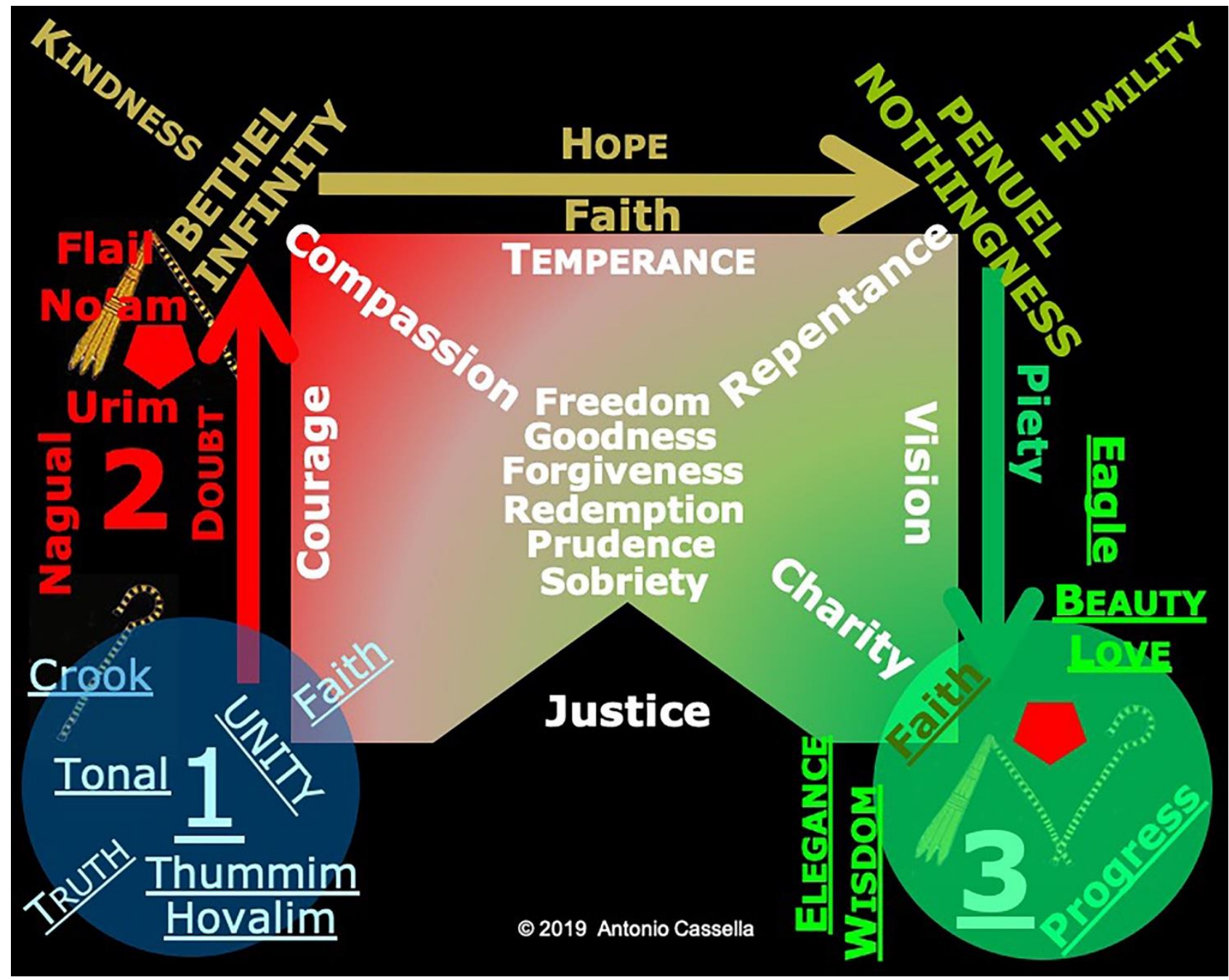

Figure 8 . The Progress of Jacob from the $1^{\text {st }}$, through the $2^{\text {nd }}$, to the $3^{\text {rd }}$ Attention

The logos heuristics allows us to ascribe the verse, "Give us this day our daily bread" of the "Lord's Prayer" to the $1^{\text {st }}$ attention; the verse, "forgive us our trespasses," to the $2^{\text {nd }}$ attention; and the verse, "as we forgive those who trespass against us," to the $3^{\text {rd }}$ Attention (Cassella, 2018c, 2018f). 
Similarly, in the prayer "Hail Mary," the verse "the Lord is with thee" points at the $3^{\text {rd }}$ Attention; the words "pray for us sinners" denote the $2^{\text {nd }}$ attention; and the words "now and at the hour of our death," the $1^{\text {st }}$ attention.

The Quran implies the selfless use of the power of the $2^{\text {nd }}$ attention in Muhammad's journey to the Farthest Mosque, while the $3^{\text {rd }}$ Attention would correspond to his return to Mecca. ${ }^{18}$ The logos heuristics allows appreciating the fact that Muhammad's return to the Black Stone matches the effects of Catholic Transubstantiation. In the same manner, the Quranic verse "Allah governs by the heaven ..." corresponds to the $2^{\text {nd }}$ attention; whereas its continuation, “. . . and by the Evening Star," agrees with the $3^{\text {rd }}$ Attention (Cassella, 2018c, 2018d, 2018f).

\section{Conclusion}

Four centuries before Heraclitus expressed his Logos, King Solomon understood the esoteric meaning of the $3^{\text {rd }}$ Attention that Moses hid in the Pentateuch and in Ark of the Covenant: The Social Relationship between visible unity (the crystal Thummim, or the Crook) and invisible nothingness-infinity (the crystal Urim, or the Flail). Conceptualizing this meaning is as simple as pursuing the values shown in Figure 8: What is true to me, may be false to you (the $1^{\text {st }}$ attention at the bottom left); we might talk about what could be good to both of us (the $2^{\text {nd }}$ attention at the center); and we may agree without talking on what is beautiful to us all (the $3^{\text {rd }}$ Attention at the bottom right).

The vanished Ark may also help us meet shared beauty, since it is more than a container. Ethiopian Christians believe that the Ark represents the mother of God, or our willingness to create God while living. As with Mary, Gabriel, and Israel after Penuel, we are free to 'walk-with-God' by using altruistically the relationship between classical and quantum computing, the crystals Thummim and Urim, or the Crook and the Flail.

Unfortunately, our time is running out. As I wrote in the past (Cassella, 2017a, 2018c, 2018f), if the temperature of the lower atmosphere on Earth rises by more than two degrees Celsius, hydrogen sulfide may leave the interphase between oxygen-fed and sulphur-fed bacteria in the oceans (Ward, 2006). This release would destroy the Ozone Shield and kill most humans and nonhuman species. The opportunity to lower the temperature of the lower atmosphere by two degrees Celsius is still open. However, we cannot rely exclusively on the wonders brought by technology.

Solar panels, wind turbines, and solar geoengineering do not suffice in educating terrorists, restoring ancient cultures, saving moribund free species, deepening the understanding of our Sacred Texts, and 'walking with' God. Global cooling should could come by reducing the 'natality rate' in developing countries and the 'per-capita consumption of energy' in developed countries - two facts that underlie an immense effort of education. Religious leaders may help.

Perhaps a Council among Abrahamic and other Faiths in Axum would re-constitute both the meaning of the Union of the crystals Urim and Thummim hidden in any Sacred Text and in the Ark-brain of most humans, boost the general will to cool Earth's atmosphere, suspend momentarily the disowning folly or ruthless lying of devious tyrants, substantiate the future blessings of our descendants, and make the Earth beautiful again!

\section{Acknowledgements}

I wish to thank my wife Ligia Uribe for her suggestions.

\section{About the author}

Placing the words "Antonio Cassella" in the space of the author at Amazon will generate the list of his works. The website at researchautism.com allows the downloading of free films and articles about Cassella's logos heuristics.

Antonio Cassella was born in Ethiopia in 1940. He had his primary education in Italy; and high-school, in both Italy and Venezuela. In 1965 he obtained from LUZ-Maracaibo a BSc in Petroleum Engineering. For the next 17 years Antonio developed oil fields in the tidal bay of Maracaibo with Creole (a subsidiary of Esso/ExxonMobil), Lagoven, and PDVSA (Petróleos de Venezuela).

In 1976, he worked with EPRCO (Exxon Production Research) in Houston; and with Strategic Planning of PDVSA between 1983 and 1993. From 1994 to 1997 he was a scientist at MIT-CEEPR (Center for Energy and Environmental Policy Research), in Cambridge (MA). His research there led to establishing two scenarios of the global growth of population, energy, and the economy; i.e., until 2060 (Cassella, 2008).

In June 1997, his exploration of the roots of autism and creative intelligence led to a master's degree in Psychology and the Award for Outstanding ALM Thesis in the Area of Natural and Human Sciences from Harvard University. In 2001 Antonio Cassella received from Universidad Nacional Experimental Simón Rodríguez (UNESR) in Caracas a doctoral degree of Research and Teaching in Sciences of Education.

His writings in Italian, Spanish, and English at Amazon and researchautism.com show that merging the local certainty

${ }^{18}$ The superior speed of the horse Burāq can be attributed to the quantum computing raised by Gabriel. 
sought by our autistic self with the nonlocal hope sought by our artistic self will allow us to restore the Commons of the Earth - among them, the atmosphere and the cycle of water.

Persons, enterprises, and institutions that face a crucial question, or want to explore the implications of the logos heuristics into a problem of their own choosing through a workshop, may e-mail Antonio Cassella at researchautism.1@gmail.com or press the tab CONTACT US at the website researchautism.com.

As shown in researchautism.com, Research Autism LLC has published 12 free documentaries (15 minutes each) about the logos heuristics. The new links are as follows:
English: (1) https://youtu.be/Py1RmzhVdO8; (2) https://youtu.be/HBU5RM3WnLE;
(3) https://youtu.be/4ug7QBm5yvo; and (4) https://youtu.be/sZrWSFFd0QA.
español: (1) https://youtu.be/y5xUVSgIiKw; (2) https://youtu.be/7m1uKY0VR4U;
(3) https://youtu.be/pHjPvIZLNRk; and (4) https://youtu.be/Ls7kDwkr-a8.
italiano: (1) https://youtu.be/2oA4f6osGHI; (2) https://youtu.be/nUzeOOgC_8A;
(3) https://youtu.be/RIqluy0b-Qs; and (4) https://youtu.be/C5JbBneJKAg.

\section{References}

Alter, R. (1996). Genesis. New York: Norton.

Anonymous. (2003). Popol Vuh: Sacred book of the Maya people. (Translation and comments by Allen J. Christenson). Mesoweb Publications.

Baktivedanta A. C. Swami Prabhuhada (1972-1983). Bhaghavad Gītā as it is. Los Angeles (CA): The Bhaktivedanta Book Trust.

Baron-Cohen, S. (1995). Mindblindness. Cambridge, MA: MIT Press.

Cappelletti, A. G. (1972). Los fragmentos de Heráclito. Caracas: Tiempo Nuevo.

Caramazza, A. (1994). Parallels and divergences in the acquisition and dissolution of language. Philosophical Transactions of the Royal Society of London, Series B. 346, 121-127. https://doi.org/10.1098/rstb.1994.0136

Cassella, A. (1997). Self-other differentiation and self-other integration from the perspectives of language development and autism. Unpublished master's thesis. Harvard University, USA.

Cassella, A. (2000). Fundamentos cognitivos y semióticos de la creatividad: Aportes del autismo. (Tesis doctoral con mención publicación). Universidad Nacional Experimental Simón Rodríguez (UNESR), Caracas, Venezuela.

Cassella, A. (2002). The Flameless Fire: From autism to creative intelligence. Quincy (MA): Logosresearch.

Cassella, A. (2008). Readjusting what we know with what we imagine. In R. Allen (Ed.), Human ecology economics: A framework for global sustainability (pp. 230-257). London: Routledge.

Cassella, A. (2011, June). Autism and the interplay of deterministic and quantum information processing in the act of creation. Neuroquantology, 9(02), 271-287.

Cassella, A. (2014). Psychological roots of social and linguistic deficiencies in autism and the distinction between classical and quantum neural computing. In V. B. Patel, V. B. Preedy, \& C. R. Martin (Eds.), The comprehensive guide to autism (pp. 1219-1242). London: Springer.

Cassella, A. (2016). The psychological roots of creativity in messages left by Leonardo da Vinci, Giorgio Vasari, and a Neanderthal troglodyte. Journal of Arts and Humanities, 5(8), 12-28. https://doi.org/10.18533/journal.v5i8.966

Cassella, A. (2017a). Re-directing climate change and terrorism by allying classical with quantum neural computing. International Journal of Social Science Studies, 5(6), 94-115. https://doi.org/10.11114/ijsss.v5i6.2439

Cassella, A. (2017b) Freeing Leonardo da Vinci's Fight-for-the-Standard in the Hall of the Five Hundred at Florence's Palazzo Vecchio. International Journal of Social Science Studies, 5(10), 01-16. https://doi.org/10.11114/ijsss.v5i10.2657

Cassella A. (2018a). A psychological view of complex numbers through classical and quantum computing. International Journal of Social Science Studies, 6(1), 66-81. https://doi.org/10.11114/ijsss.v6i1.2872

Cassella A. (2018b). Exploring the social link between cerebral and cerebellar neural ensembles through a falsifiable psychological heuristics. International Journal of Social Science Studies, 6(2), 69-93, https://doi.org/10.11114/ijsss.v6i2.2934. 
Cassella, A. (2018c). Series, Thus returned Quetzalcoatl: Labyrinth 1 (The way of hunting), Labyrinth 2 (The way of war), and Labyrinth 3 (The way to progress). Melbourne (FL): Research Autism (4 ${ }^{\text {th }}$ edition at Amazon Prime and Kindle).

Cassella, A. (2018d). An unlawful look at an extraordinary theory-of-everything: Answers to 15 questions concerning the dance of locality with nonlocality. Melbourne (FL): Research Autism (4 ${ }^{\text {th }}$ edition at Amazon Prime and Kindle).

Cassella, A. (2018e). Exploring the Sphinx and the Great Pyramid through the logos heuristics. International Journal of Social Science Studies, 6(9), 11-30. http://redfame.com/journal/index.php/ijsss/issue/view/164

Cassella, A. (2018f). Re-directing climate change and terrorism by allying classical computing and quantum computing. Melbourne (FL): Research Autism (4 ${ }^{\text {th }}$ edition at Amazon Prime and Kindle).

Castaneda, C. (1968). The teachings of Don Juan: A Yaqui way of knowledge. New York, Simon and Schuster, 1968.

Castaneda, C. (1972). Journey to Ixtlán: The lessons of Don Juan. New York: Simon and Schuster.

Castaneda, C. (1974). Tales of Power. New York: Simon and Schuster.

Feynman, R. P. (1985). The strange theory of light and matter. Princeton, N.J.: Princeton University Press.

Hancock, G. (1992). The sign and the seal: The quest for the lost Ark of the Covenant. New York: Crown Publishers.

Icke, V. (1995). The force of symmetry. Cambridge: Cambridge University Press.

Ito, M. (1993). New concepts in cerebellar function. Revue Neurologique, 149(11), 596-599.

Ito, M. (2011). The cerebellum: Brain for an implicit self. Upper Saddle River, NJ: Pearson Ed.

Katznelson, M. (1991). La Biblia: hebreo-español. Tel Aviv: Sinai.

Kong-Fuzi ( $5^{\text {th }}$ century BCE-1995). The Analects. New York: Dover.

Lao Tze, (1891). Tao Te Ching. Oxford: Oxford University Press.

Perner, J. (1991). Understanding the representational mind. Cambridge (MA): MIT Press.

Povinelli, D. J, Landau, K. R, \& Perilloux, H. K. (1996). Self-recognition in young children using delayed versus live feedback: Evidence of a developmental asynchrony. Child Development, 67, 1540-1554. https://doi.org/10.2307/1131717

Rodríguez-Vidal, J., d'Errico F., Giles Pacheco, F., Blasco, R., Rosell, J., Jennings, R. P., ... Finlayson, C. (September 2014). A rock engraving made by Neanderthals in Gibraltar. Proceedings of the National Academy of Sciences of the United States of America, 111(37), 13301-13306. https://doi.org/10.1073/pnas.1411529111

Rosmini, A. (1848). Delle cinque piaghe della Chiesa: Trattato dedicato al clero cattolico. Bruxelles: Société Typographique (Wikisource, 2018).

Rowling, J. K. (1997). Harry Potter and the philosopher's stone. London: Bloomsbury.

Rowling, J. K. (1999). Harry Potter and the prisoner of Azkaban. New York: Scholastics.

Vālmīki, R. (5 ${ }^{\text {th }}$ century BCE-2018). Rāmāyana: An Epic of Ancient India, Volume VII: Uttarakānḍa (Translation and introduction by R. P. Goldman and S. Sutherland Goldman). Princeton: Princeton University Press.

Villalba, D. (1989). La enseñanza de Vimalakirti: Vimalakirti Nirdesa Sutra. Madrid: Mirasano.

Ward, P. D. (October 2006). “Impact from the Deep.” Scientific American, 295, 64-71.

Zaitchik, D. (1990). "When representations conflict with reality: The preschooler's problem with false beliefs and 'false' photographs.” Cognition, 35, 41-68. https://doi.org/10.1016/0010-0277(90)90036-J

\section{Copyrights}

Copyright for this article is retained by the author(s), with first publication rights granted to the journal.

This is an open-access article distributed under the terms and conditions of the Creative Commons Attribution license which permits unrestricted use, distribution, and reproduction in any medium, provided the original work is properly cited. 